\title{
Metabolic rates and primary productivity of the marine macroalgae Dictyopteris delicatula in Taganga Bay, Colombian Caribbean
}

Tasas metabólicas y productividad primaria de la macroalga marina Dictyopteris delicatula en la Bahía de Taganga, Caribe Colombiano

\section{Juan Diego Gaitán-Espitia ${ }^{1,2}$}

\author{
${ }^{1}$ Instituto de Ecología y Evolución, Facultad de Ciencias, Universidad Austral de Chile, Casilla 567 Valdivia, Chile. \\ juadiegaitan@gmail.com \\ ${ }^{2}$ Centro de Investigaciones en Zoología y Ecología Marina (CIZEM), Santa Marta, Colombia
}

\begin{abstract}
Metabolic rates and photosynthetic performance of Dictyopteris delicatula were measured in the south of Taganga Bay and on Inca-Inca beach, Colombia, during September and November 2007, as part of a monitoring program of water quality and pollution associated with the stormwater system of the city of Santa Marta. Concentrations of chlorophyll-a of D. delicatula did not show significant differences between both areas but the average rates of net primary productivity and respiration differed significantly, likely due to the effect of the nutrient loadings from the stormwater outlet in Taganga Bay, altering the physiological processes of the macroalgal community.
\end{abstract}

Key words: Phaeophyta, photosynthesis, respiration, metabolism, Colombia

\section{INTRODUCTION}

Primary productivity is the rate at which energy is stored as organic matter in plants per unit area (Fahey \& Knapp 2007). Oceans cover the greater part (70\%) of the Earth's surface, but total oceanic net primary production is less (45\%) than terrestrial primary production (55\%), principally due to the limitation of nutrients in the illuminated surface waters of most open ocean areas (Mackenzie 2005). Although phytoplankton contributes substantially towards the primary productivity of coastal areas, there are certain areas along the coastal belt where production of benthic macrophytes exceeds that of phytoplankton (Dhargalkar \& Shaikh 2000). Most coastal areas provide both autochthonous and allochthonous sources of nutrients which result in high primary productivity supporting secondary production. Calculations of primary and secondary productivity in marine communities to estimate metabolic rates are essential to the understanding of trophic web structure and energy and material transfer in marine environments (Carpenter et al. 1991).

In many coastal areas along the north coast of the Colombian Caribbean, abundant rocky substrata support a variety of benthic macroalgae communities. In particular, within the Atlantic region of Colombia, the class Phaeophyceae is represented by 71 species, with Dictyopteris accounting for roughly $5.6 \%$ of total diversity
(Díaz-Pulido \& Díaz-Ruíz 2003). According to Taylor (1960), one of the most common species of the genus in the Caribbean is Dictyopteris delicatula, where it is widely distributed throughout a variety of habitats. The alga commonly grows epiphytically in shallow waters but can also occur down to $30 \mathrm{~m}$ depth (Allender \& Kraft 1983).

This study was undertaken to investigate metabolism in terms of primary productivity, respiration and photosynthesis of a dominant macroalgal population, Dictyopertis delicatula, from the rocky intertidal shore in the south of Taganga Bay following the installation of stormwater culvert drainage system for the city of Santa Marta. There is abundant evidence of the suitability of benthic macrophytes as biological indicators of the effects of pollution gradients (Juanes et al. 2008). There is also evidence that the nutrient loadings from coastal watersheds, stormwater outlets, septic tanks and others sources, are the most widespread factor that alters structure and function of receiving aquatic ecosystems (Valiela et al. 1992). According to this approach, the hypothesis tested was that $D$. delicatula exhibits higher metabolic rates near Taganga Bay than in coastal areas far away from the city (i.e., Inca-Inca beach) as a result of the influence of the stormwater culvert drainage and the increase in the nutrient input caused by it, where the effect of the run-offs have a direct impact on the macroalgal community. 


\section{MATERIAL AND METHODS}

The study site was located on a rocky intertidal shore near the exit of the stormwater culvert drainage system in the south of Taganga Bay $\left(11^{\circ} 15^{\prime} 27^{\prime \prime N} \mathrm{~N} ; 4^{\circ} 12^{\prime} 15^{\prime \prime} \mathrm{W}\right)$. A control area $\left(11^{\circ} 12^{\prime} 44^{\prime \prime} \mathrm{N} ; 74^{\circ} 14^{\prime} 02^{\prime \prime} \mathrm{W}\right)$ was located at Inca-Inca Beach (Fig. 1), at a sufficient distance so as not to be under the influence of run-offs from the stormwater culvert drainage system of Santa Marta City.

Dictyopteris delicatula displays high percentage cover (35\%) in both areas. The algae were collected and incubated (6 hours) once during the rainy season (SeptemberNovember) of 2007, at both sites of collections at the same time (i.e., between 10 a.m. and 4 p.m.) under natural conditions (i.e., $28^{\circ} \mathrm{C}$ and $35 \mathrm{psu}$ ) at $1 \mathrm{~m}$ depth, utilizing the light and dark bottle method, to estimate primary productivity and respiration according to Howarth \& Michaels (2000).

Incubations were conducted in Falcon tubes of $50 \mathrm{ml}$ with filtered natural seawater, carefully sealed to avoid air bubbles. Ten individuals (each thallus of $2.3 \pm 0.04 \mathrm{~g}$ wet weight) and two sets of light and dark bottles were used for each location; while a set of dark and light bottles incubated without algae served as control. The initial oxygen content was measured before and after each set of experimental bottles was filled with sea water. The oxygen values in light and dark bottles used as control remained constant, so blank corrections need not be applied. Variables such as dissolved oxygen (DO), water temperature, electrical conductivity, and $\mathrm{pH}$ were measured at the water column and tubes using digital portable equipments (oximeter YSI model 55 and potentiometer Hatch). Chlorophyll $a$ extraction was obtained by the immersion of the thallus in acetone neutralized with $\mathrm{MgCO}_{3}$ and stored in dark conditions during $24 \mathrm{~h}$ at $4^{\circ} \mathrm{C}$.
In order to eliminate turbidity, the extracts were centrifuged at $5500 \mathrm{~g}$ for $20 \mathrm{~min}$. Chlorophyll $a$ concentration was determined using a Hach DR 2010 spectrophotometer and applying the Inskeep \& Bloom (1985) equation. Metabolic rates of Dictyopteris delicatula in both sites of study were compared using the Mann-Whitney U test with a level of significance of 5\%. Two-way ANOVA was used to compare the pigment content using sampled sites (i.e., Taganga Bay and Inca-Inca beach) and bottles (i.e., light and dark bottle) as fixed factors. For all data, Shapiro-Wilks test for normality and Levene's test for homogeneity of variance were made. Differences were considered significant at $P<0.05$. All statistical analyses were performed using STATISTICA 7.0 software (StatSoft, Inc.).

\section{RESUlTS AND DISCUSSION}

The macroalgae community composition of the rocky intertidal shore in the Taganga Bay was mostly dominated, in percentage cover, by the brown seaweed Dictyopteris delicatula, followed by Centroceras micracanthum, Padina gymnospora and Jania adhaerens. It is a prerequisite to understand the metabolism of the macrophytic community in order to determine the photosynthetic rates of the dominant (in terms of cover) populations (Littler \& Murray 1975).

The average rate of Gross Primary Production (GPP) for individuals collected near the fluvial exit of the culvert was $24.7 \mathrm{mgC} \mathrm{g} \mathrm{dry} \mathrm{wt}^{-1} \mathrm{~h}^{-1}$, while at Inca-Inca Beach average GPP was $12.3 \mathrm{mgC} \mathrm{g} \mathrm{dry} \mathrm{wt}^{-1} \mathrm{~h}^{-1}$ (Table 1 ). Average rates of Net Primary Productivity (NPP) and Respiration (R) differed significantly between the two populations sampled (MannWhitney U test, $\mathrm{Z}=3.78, P<0.005)$. On the other hand, the analysis of chlorophyll $a(\mathrm{Chl} a$ ) concentration (Fig. 2) did

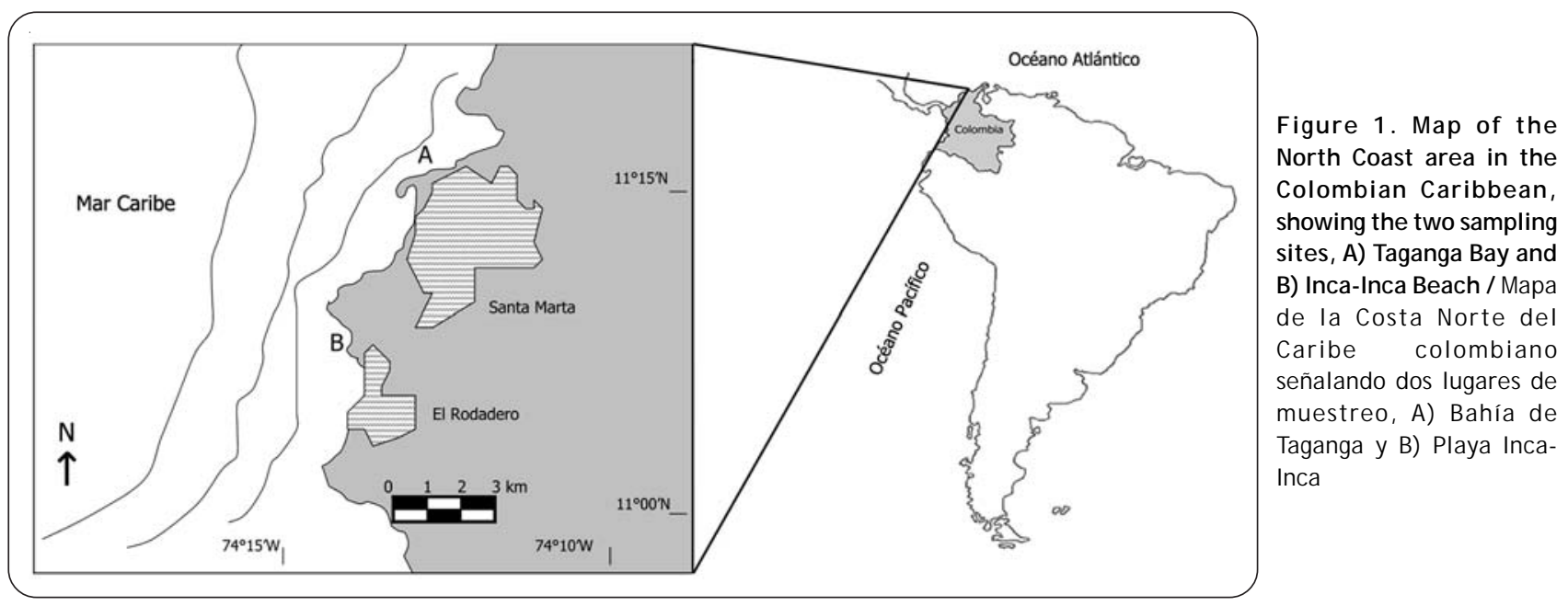




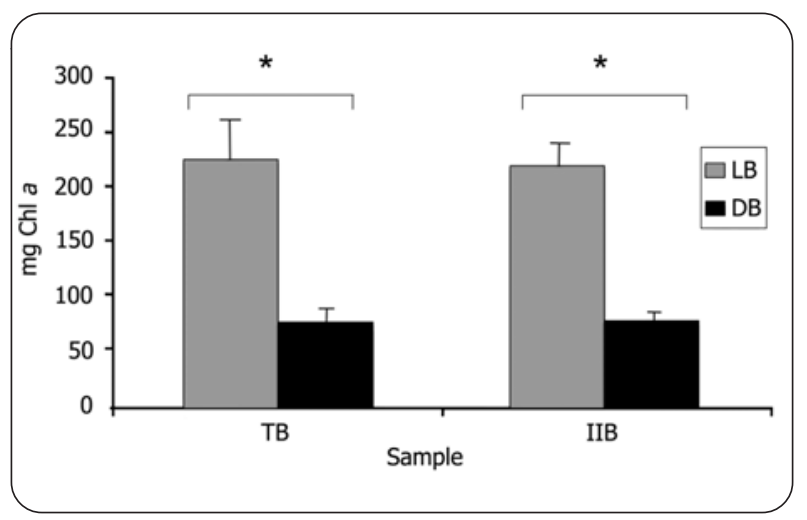

Figure 2. Chlorophyll-a concentration per gram (g) of algae in the two sampling sites, Taganga Bay (TB) and Inca-Inca Beach (IIB), using the Light Bottle (LB) and the Dark Bottle (DB) method. *: significant differences at $\mathbf{P}<\mathbf{0 . 0 5} /$ Concentraciones de Clorofila-a por gramo (g) de alga, en los dos lugares de muestreo, Bahía de Taganga Bay (TB) y Playa Inca-Inca (IIB), mediante el uso del método de Botellas Claras (LB) y Oscuras (DB). *: diferencias significativas con un $\mathrm{P}<0,05$

not show significant differences between the two sample areas (two-way ANOVA, $\mathrm{F}_{1,36}=0.143, P=0.707$ ), but differed significantly between the bottles (two-way ANOVA, $\left.\mathrm{F}_{1,36}=198.87, P<0.001\right)$.

The metabolic performance of Dictyopteris delicatula in the present study showed superior values to other marine macrophytes and macroalgae (Littler \& Arnold 1982, Dhargalkar \& Shaikh 2000, Raven \& Taylor 2003). From a functional-form group perspective, several authors have reported that the magroalgal sheet-like groups (e.g., Dictyopteris sp., Dyctiota sp., Ulva sp., etc.) are characterized by higher photosynthetic performance rates than other functional-form groups (e.g., delicatelled- branched group) with, for example, NPP rates ranging between 5.6 and $26.99 \mathrm{mgC} \mathrm{g}$ dry wt $^{-1} \mathrm{~h}^{-1}$ (Littler \& Arnold 1982, De los Santos et al. 2009) which is consistent with the values found in the present study. On the other hand, in the analysis of primary productivity and pigment content, weights of algal thalli were standardized to compare between the dark and light bottles. It is important to highlight that the significant differences in Chl $a$ concentrations between dark and light bottles at both sampled sites (less Chl $a$ content in algae from dark incubations; Fig. 2), could be explained by differences in maturity stages of the thalli used for this analysis. In effect, in other algae the cost of reproduction (i.e., trade-offs between reproduction and performance), causes non-mature thallus to have higher pigment concentrations, higher primary production, higher respiration and better capacity to generate new apex rather than mature thallus, suggesting that reproduction exhausts nutrients or energy of an organism, thereby reducing its capacity for vegetative growth or its ability to invest in future reproduction (Guillemin, pers. comm.) ${ }^{1}$. Additionally, primary productivity in macroalgae is strongly dependent on the proportion of the tissue effectively involved in photosynthesis (i.e., large thalli with relatively high proportions of structural and non-photosynthetic tissues have lower photosynthesis rates than thalli consisting mostly of photosynthetically active cells), so it is plausible that different parts of the thallus have different physiological parameters related to size and age, producing different profiles for photosynthesis and carbon fixation (Gómez et al. 1996). Unfortunately, it was not possible to determine the maturity stages or the age of the algae thalli used in this study.

Table 1. Mean ( \pm SD, standard deviation, $\mathbf{n}=10$ ) primary productivity of Dictyopteris delicatula in the Taganga Bay and in the Inca-Inca Beach, and comparisons between the two localities through the Mann-Whitney U test. Gross Primary Production (GPP), Net Primary Productivity (NPP) and Respiration (R) / Productividad primaria promedio ( \pm SD, desviación estándar, n=10) de Dictyopteris delicatula en la Bahía de Taganga y la Playa de Inca-Inca Beach, y su comparación entre las dos localidades a través de la prueba U de Mann-Whitney. Producción Primaria Bruta (GPP), Producción Primaria Neta (NPP) y Respiración (R)

\begin{tabular}{|c|c|c|c|c|c|c|c|c|}
\hline \multirow{3}{*}{$\begin{array}{l}\text { Metabolic } \\
\text { rate }\end{array}$} & \multicolumn{4}{|c|}{$\begin{array}{l}\text { Mean Productivity } \\
\left(\mathrm{mgC} \mathrm{g} \text { dry } \mathrm{wt}^{-1} \mathrm{~h}^{-1}\right)\end{array}$} & \multicolumn{4}{|c|}{$\begin{array}{c}\text { Productivity } \\
\text { Algae } 1 \mathrm{~g} \\
\left(\mathrm{mgC} \mathrm{mgChl} a^{-1} \mathrm{~h}^{-1}\right)\end{array}$} \\
\hline & \multirow[t]{2}{*}{$\begin{array}{c}\text { Taganga Bay } \\
\mathrm{X} \pm \mathrm{SD}\end{array}$} & \multirow[t]{2}{*}{$\begin{array}{c}\text { Inca-Inca Beach } \\
\mathrm{X} \pm \mathrm{SD}\end{array}$} & \multicolumn{2}{|c|}{$\begin{array}{c}\text { Mann-Whitney U } \\
\text { test }\end{array}$} & \multirow[t]{2}{*}{$\begin{array}{c}\text { Taganga Bay } \\
X \pm \text { SD }\end{array}$} & \multirow[t]{2}{*}{$\begin{array}{c}\text { Inca-Inca Beach } \\
X \pm S D\end{array}$} & \multicolumn{2}{|c|}{$\begin{array}{c}\text { Mann-Whitney L } \\
\text { test }\end{array}$} \\
\hline & & & $\mathrm{Z}$ & $P$ & & & $\mathrm{Z}$ & $P$ \\
\hline GPP & $24.70 \pm 2.13$ & $13.7 \pm 2.24$ & 3.64 & 0.00015 & $0.116 \pm 0.008$ & $0.078 \pm 0.01$ & 3.64 & 0.00015 \\
\hline NPP & $22.24 \pm 1.98$ & $12.3 \pm 1.73$ & 3.78 & 0.00018 & $0.084 \pm 0.011$ & $0.061 \pm 0.03$ & 3.77 & 0.00018 \\
\hline $\mathrm{R}$ & $2.46 \pm 0.21$ & $1.4 \pm 0.18$ & 3.93 & 0.00013 & $0.032 \pm 0.007$ & $0.017 \pm 0.01$ & 3.98 & 0.00013 \\
\hline
\end{tabular}

\footnotetext{
${ }^{1}$ Ms. Marie Laure Guillemin, Instituto de Ecología y Evolución, Universidad Austral de Chile.
} 
The results presented here partially support the tested hypothesis and show that the population of Dictyopteris delicatula from the rocky intertidal shore in the south of Taganga Bay had higher metabolic rates than the population from Inca-Inca Beach, probably due to the increase in nutrients associated with the stormwater drainage system of Santa Marta City. The difference in metabolic performance between the two populations of $D$. delicatula could derive from trade-offs between growth, reproduction and survival (i.e., fitness), and constrain the capability to respond to environmental disturbance. It is important to consider the tidal effects on photosynthetic performance of algae, due to the variations in irradiance levels associated with photoinhibition of photosynthesis and deep oxidation (Hanelt et al. 1994). The collected samples of $D$. delicatula were obtained from the midlittoral zone, where the algae are covered and uncovered twice a day by the tides, and under these conditions populations presented higher rates of photoinhibition than algae from the infralittoral zone, where they are protected from the high rates of solar radiation remaining and submerged for a longer period of time (Gómez et al. 2004). Therefore, the macroalgae growing in the midlittoral zone of the rocky shore have lower photosynthetic rates and primary productivity than macroalgae in the infralittoral zone (Gómez et al. 2005).

The values of metabolic rates and primary productivity were different for both populations of Dictyopteris delicatula between Taganga Bay (influenced by the stormwater drainage system) and Inca-Inca beach (without influence of the run-offs from the stormwater drainage system). However, future studies are needed to address the following questions: a) Do the variations of the environmental characteristics (i.e., nutrient and sediment fluxes, turbidity, etc) associated with the stormwater drainage system influence the metabolic rates and photosynthetic performance of Dictyopteris delicatula and other macroalgae in the study area?; b) What is metabolic and photosynthetic response of different maturity stages of macroalgae to the variation in nutrient and sediment fluxes from the stormwater system run-offs?

\section{ACKNOWLEDGMenTs}

The author expresses his gratitude to the members of the Centro de Investigaciones en Zoología y Ecología Marina CIZEM. I would also like to thank the three anonymous reviewers for their useful recommendations that substantially improved this manuscript.

\section{LITERATURE CITED}

Allender B \& G Kraft. 1983. The marine algae of Lord Howe Island (New SouthWales): Dictyotales and Cutleriales (Phaeophyta). Brunonia 6: 73-130.

Carpenter R, J Hackney \& W Adey. 1991. Measurements of primary productivity and nitrogenase activity of coral reef algae in a chamber incorporating oscillatory flow. Limnology and Oceanography 36: 40-49.

De los Santos CB, JL Pérez-Lloréns \& JJ Vergara. 2009. Photosynthesis and growth in macroalgae: linking functional-form and power-scaling approaches. Marine Ecology Progress Series 377: 113-122.

Dhargalkar V \& N Shaikh. 2000. Primary productivity of marine macrophytes in the coral reef lagoon of the Kadmat Island, Lakshadweep. Current Science 8: 1101-1104.

Díaz-Pulido G \& M Díaz-Ruíz. 2003. Marine macroalgal diversity of the Colombian Atlantic. Biota Colombiana 4: 203-246.

Fahey T \& A Knapp. 2007. Primary production: Guiding principles and standards for measurement. In: Fahey TJ \& AK Knapp (eds). Principles and standards for measuring net primary production, pp. 3-11. Oxford University Press, New York.

Gómez I, C Wiencke \& DN Thomas. 1996. Variations in photosynthetic characteristics of the Antarctic marine brown alga Ascoseira mirabilis in relation to thallus age and size. European Journal of Phycology 31: 167-172.

Gómez I, FL Figueroa, N Ulloa, V Morales, C Lovengreen, P Huovinen \& S Hess. 2004. Patterns of photosynthesis in 18 species of intertidal macroalgae from southern Chile. Marine Ecology Progress Series 270: 103-116.

Gómez I, F Figueroa, P Huovinen, N Ulloa \& V Morales. 2005. Photosynthesis of the red alga Gracilaria chilensis under natural solar radiation in an estuary in southern Chile. Aquaculture 244: 369-382.

Häder D, M Porst \& M Lebert. 2001. Photosynthetic performance of the Atlantic brown macroalgae, Cystoseira abiesmarina, Dictyota dichotoma and Sargassum vulgare, measured in Gran Canaria on site. Environmental and Experimental Botany 45: 21-32

Hanelt D, J Li \& W Nultsch. 1994. Tidal dependence of photoinhibition of photosynthesis in marine macrophytes of the South China Sea. Botanica Acta 107: 66-72.

Howarth R \& A Michaels. 2000. The measurement of primary production in aquatic ecosystems. In: Sala OE, RB Jackson, HA Mooney \& RW Howarth (eds). Methods in ecosystem science, pp. 74-85. Springer-Verlag, New York.

Inskeep WP \& PR Bloom. 1985. Extinction coefficients of chlorophyll $a$ and $b$ in N, N-dimethylformamide and $80 \%$ acetone. Plant Physiology 77: 483-485 
Juanes J, X Guinda, A Puente \& J Revilla. 2008. Macroalgae, a suitable indicator of the ecological status of coastal rocky communities in the NE Atlantic. Ecological Indicators 8: 351-359.

Littler M \& S Murray. 1975. The primary productivity of marine macrophytes from a rocky intertidal community. Marine Biology 27: 131-135.

Littler M \& K Arnold. 1982. Primary productivity of marine macroalgal functional-form groups from Southwestern North America. Journal of Phycology 18: 307-311.

Mackenzie F. 2005. Boundary exchanges in the global costal margin: Implications for the organic and inorganic carbon cycles. In: Robinson AR \& KH Brink (eds). The global coastal ocean. Multiscale interdisciplinary processes. The sea: ideas and observations on progress in the study of the seas, pp. 119-126. Harvard University Press, Cambridge.

Raven JA \& R Taylor. 2003. Macroalgal growth in nutrientenriched estuaries: a biogeochemical and evolutionary perspective. Water, Air, \& Soil Pollution: Focus 3: 7-26.

Taylor W. 1960. Marine algae of the eastern tropical and subtropical coasts of the Americas, 870 pp. University of Michigan Press, Ann Arbor.

Valiela I, K Foreman, M Lamontagne, D Hersh, J Costa, P Peckol, B Demeo-Anderson, C D’Avanzo, M Babione, CH Sham, J Brawley \& K Lajtha. 1992. Couplings of watersheds and coastal waters: Sources and consequences of nutrient enrichment in Waquoit Bay, Massachusetts. Estuaries 15: 443-457.

Received 30 March 2010 and accepted 21 October 2010 